University of Michigan Law School

University of Michigan Law School Scholarship Repository

\title{
The Disposition to Be Made of Property the Subject of a Power if the Power Is Not Exercised
}

\author{
John R. Rood \\ University of Michigan Law School
}

Available at: https://repository.law.umich.edu/articles/1357

Follow this and additional works at: https://repository.law.umich.edu/articles

Part of the Common Law Commons, Estates and Trusts Commons, Property Law and Real Estate Commons, and the State and Local Government Law Commons

\section{Recommended Citation}

Rood, John R. "The Disposition to Be Made of Property the Subject of a Power if the Power Is Not Exercised." Mich. L. Rev. 15 (1917): 386-412.

This Article is brought to you for free and open access by the Faculty Scholarship at University of Michigan Law School Scholarship Repository. It has been accepted for inclusion in Articles by an authorized administrator of University of Michigan Law School Scholarship Repository. For more information, please contact mlaw.repository@umich.edu. 


\section{THE DISPOSITION TO BE MADE OF PROPERTY THE SUBJECT OF A POWER IF THE POWER IS NOT EXERCISED.}

\section{The Classes of Cases.}

The object sought in this article is to collect and classify the cases in which the courts have passed on the question as to what shall be done with property over which a power of appointment has been given; when it finally turns out for some reason that the power has not been exercised. ${ }^{1}$ It is not the object to establish any particular thesis, but rather to ascertain how the adjudicated cases stand.

The Classes of Cases involving the question of whether persons are to take under a gift, or under a trust, or are not to take at all, if no appointment is made, are:

I. An express gift to objects, with merely a power to someone to divest the shares or proportions by making an appointment.

2. Where the intent that the objects shall take is clearly manifested though not expressly stated, and the power is merely to divest as above.

3. Where the property is given to a trustee (without or with a beneficial interest to himself) and he is empowered to appoint out of his estate.

4. Where there is no expressed nor clearly manifested intent to give to the objects claiming in default of appointment, and the property is not held in trust by the donee of the power.

I. AN EXPRess GiFT SUBJEct to A Power to someone to divest or alter the interest or share of the donee or donees vests as if no power had been given, and in default of appointment, or to the extent that the property is not effectually appointed, remains in them undivested as if no power had been given. ${ }^{2}$

1 The most extensive collection of cases found in preparation of this article is an article by Professor John C. Gray in 25 Harvard Law Review, pp. 1-30.

axpress Gift Subject to Power.

Bellisis v. Uthwatt (I737), I Atk. I43, was a marriage settlement by the husband of annuities in trust for himself for life, remainder to his children as he should appoint, and if no children, to his executors; and Iord Hardwicke held on death of the husband leaving one child and the power unused, that she took a vested interest in the whole subject only to the power to alter shares if there were more than one child.

Casterton v. Sutherland (1804), 9 Ves. 445, 5 Gray Cas. (and ed.) 336 , was a devise of a freehold to testator's wife for life, and after her decease to his children in such manner and proportions as she should in her life or by will appoint. He died leaving five infant children, of whom three sons died infants unmarried. The remaining son died before his mother, leaving issue (a daughter) and his sister surviving. The sister also died before her mother, leaving issue ( $a$ son). Testator's widow having died with. out attempting to exercise the power, Sir Wm. Grant, M. R., held that the children 
took fifths in fee as tenants in common subject to the life estate and the power never exercised, and that the daughter of the son took four-fifths as heir of her father who had inherited the shares of the uncles, and that the other share went to the daughter's son by inheritance from her.

Robinson v. Smith (1821), 6 Madd. 193; Burrough v. Philcox (1840); 5 Mylne \& Cr. 72, 5 Jur. 453 .

Lambert v. Thwaites (1866); I. R. = Eq. Cas. 151, 35 I. J. Ch. 406, I4 I. T. I59, I4 W. R. 532: "The general principle seems to be this: If the instrument itself gives the property to a class, but gives a power to A to appoint in what shares, and in what manner the members of that. class shall take, the property vests (until the power is exercised) in all the members of the class, and they will take in default of appointment; but if the instrument does not contain a gift of the property to any class, but only a power to $A$ to give it as he may think fit, among the members of that class, those only can take in default of appointment who might have taken under an exercise of the power. In that case the court implies an intention to give the property in default of appointment to those only to whom the donce of the power might give it." Per Kindersley, V. C., who held that $\mathbf{X}$, who died before the life tenant having the power, had vested interests which passed to his heir, though there were no pords of gift to the children apart from the direction to the trustee to divide among the children on the death of testator's widow as she should by will appoint.

Wilson v. Duguid (1883), 24 Ch. D. 244,53 L. J. Ch. 52, 49 I. T. 124, 31 W. R. 945, 5 Cray Cas. (2nd ed. 347), was an assignment of a term to son and son-in-law in trust for the separate use of the daughter for life and, if she have no issue, to the son for life, then in trust to assign among his children as he should appoint. The son died before the daughter. She had no children, and he had ten, of whom three died before him, and one later before the daughter. The power was never exercised. Chitty, J., said: "On the true construction of this settlement, so far as relates to the children of Robert Keeling the younger, I hold that there is a trust for all the children of Robert in equal shares, subject to a power of selection and distribution exercisable by him by deed inter vivos or by a testamentary instrument. That appears to me to be the plain construction of the words I have read. The whole of the property is vested in trustees, there is contained a trust in the words 'upon trust to assign' distinguishable from the power which is conferred upon Robert Keeling the younger. The objects of the power are not any of the children, though there is a power of selection and a power to exclude, not particular children of Robert, but all his children. There was no time limited for the execution of the power, and it was not more or less his duty to exercise the power just before his death than it was to exercise it at any other time."

Phene's Trusts (1868), I. R. 5 Eq. Cas. 346, 5 Gray Cas: (2nd ed.) 346, was a gift to testator's executors in trust to the use of his daughter for life, then "in trust for the benefit of her children, to do that which they, my executors, may think most to their advantage." The daughter had five children, of whom three died in her lifetime, and only those surviving their mother took. Lord Romilly, 31. R., said, "Now the gift here is from and after the death of the tenant for life, for the benefit of her children, to do that which the executors might think most to their advantage. I think that gives the fund to the executors' to divide among the class of children who survive the tenant for life." This case seems in conflict with the preceding cases, but has been justified on the ground that the Master of the Rolls found that personal enjoyment by the children was intended. The same has been said of White's Trusts, John. 656.

Allen v. Davies (1912), 85 Conn. 172, 82 At1. 189, was a devise to the testator's son in trust to use the income so far as needed by himself, and to divide the corpus among his children and the representatives of any child dying, with power to advance to any child at discretion. The son willed the property to trustees to pay the income to his children with power to advance to any child, and to pay the income of the share of any child dying to his or her Iepresentative; and it was held that the second will exceeded the power in the first and was void for perpetuity as far as it attempted to give a share to the isstue of the deceased child; but that the share vested in such child by the first will continued. 


\section{A MANIFESTED INTENTION WITHOUT WORDS OF GiFT has the same effect as an express gift. ${ }^{3}$}

$A$ gift to one Beneficially with Power to sell, settle, etc., may mean merely with the power resulting from such ownership, in which case the words as to the power are merely surplusage and nugatory."

Grayson v. Germania Bank (1913), 140 Ga. 467, 79 S. F. 124, semble, holding an excessive appointment to part of the class void only as to the excess.

Wetmore v. Henry (1913), 259 III. 80, 102 N. E. 189, was a gift by will of residue to one of testatrix's heirs, saying, "Hle shall make such distribution of my property among my heirs at law in such proportions as he in his discretion shall deem each of them worthy ;" and the trustee paid one $\$ 500$, took a receipt in full, died without further exercise of the power and the unappointed part was divided among all equally.

Cathey v. Cathey (1848), 9 Humph. (28 Tenn.) 470, 49 Am. Dec. 714, holding children of testator who died before their mother, who had gift in trust with power to divide among children when and as she pleased, took vested estates not defeated by their death and her failure to divide.

Millikin v. Welliver (I882), $37 \mathrm{Oh}$. St. 460 , holding "the residue of my estate is to be distributed to the heirs of my side of the house in such portions as she may direct" entitles the heirs not the personal representatives on her death without appointme- no discussion.

Gorin v. Gordon (1859), 38 Miss. 205, holds that the rights of issue of the marriage, under ante-nuptial settlement to trustees to use of father and mother for life, then to the children as he should by will appoint, are not defeated by the father's sale of the property to defendants.

McCamant v. Nuckolis (1888), 85 Va. 33I, 12 S. E. I60, sustaining an unequal appointment, and declaring that the court will not interfere in the absence of fraud.

Leake says: "Where there is a gift to children with a power of apportioning the shares in which they are to take-as; to all the children of $A$ in such shares as $A$ should appoint by will, - the children take vested interests by the express terms of the gift, subject to be divested by the exercise of the power; and children dying in the lifetime of the parent will remain entitled in default of appointment, notwithstanding the power (being by will only) is restricted to those living at the death of the parent." Leake Dig. 391:2, citing Casterton v. Sutherland, 9 Ves. 445, and Lambert v. Thwaites, I. R. 2 Eq. Cas. 15 r.

3 Manifest Intent Without Express Gift.

"I avoid using the expression 'power coupled with a trust,' as being more properly applicable where the donee takes some interest in the estate which is the subject of the power. It is enough if the power is coupled with such an indication of an intention to benefit the objects of it as, in default of appointment, will imply a gift to them in preference to the heir at law," per FitzGibbon, L. J., in Sinnott v. Walsh (1880), 5 L. R. Ir. $27 \times 39$, holding "to fall to whatever existing member of my family he may be disposed to will it," entitles all children to take in default of selection.

Smith $\nabla$. Floyd (1893), 140 N. Y. 337, 35 N. I. 606.

Jones's Estate ( 1893$), 84$ Wis. 465,54 N. W. 917 , was a devise of all to wife (sole executrix) for her own benefit for life, and "I will and direct" my said executrix to devise two-thirds of my estate "to whomsoever of my nearest relations as will look reasonable to her." She died without executing the trust; and the nearest relations were held entitled to the appointment of an administrator de bonis non, either by virtue of the gift, or as next of kin for so much intestate.

4 Power of Ownership Merely.

Brook v. Brook (1856), 3 Sur. \& Giff. 280, was a devise of copyhold to Mary to her separate use without any words to indicate whether she took for her life or in fee, "with power" to appoint it to her children and husband; Stuart, V. C., held she took in fee subject to no trust.

Lambe v. Eames (1870), L. R. ro Eq. 267, affirmed on appeal in (1871), L. R. $6 \mathrm{Ch}$. App. 597. A bequest of everything to his widow "to be at her disposal in any 


\section{It may be construed to Create a Precatory Trust."}

way she may think best for tne benefit of herself and family," was held to be an absolute gift and not a trust for the children of the testator.

In re Hutchinson (1878), 8 Ch. D. 540, 39 L. T. 86, 26 W. R. 904, holding gift "absolutely with full power" to dispose, etc., was fee absolute, not a trust.

- Precatory Trusts.

If property is given in fee with language which amounts to a precatory trust, the trist will fasten itself on the inheritance, the donee will be bound to execute it, and if he fail to do so the court will carry it into effect as if he had. If, on the other hand, the words used in giving the power indicate that a mere power was intended, and do not impose any obligation, the court will treat such a power as mere surplusage, being no more than authorized by virtue of ownership. But if it is apparent that the conveyance

- to the donee is itself a conveyance to him as trustee, the power in that case becomes an imperative trust without intent to command appearing. See Moore v. Ffolliot (1887), I. R. Ir. 499, 5 Gray Cas. (ind ed.) 352, 353.

Malim v. Keighley (I794), 2 Ves. Jr. 333 r 529, was a gift of stock in trust with gift over of residue after expiration of the trusts to daughter "recommending it to such daughter to dispose of the same after her own death" to children of A and J. Held 2 trust for such children.

Forbes v. Ball (1817), 3 Meriv. 437, "I give to A. C. $f 500$ and it is my will and desire that $A$. C. dispose of the same among her relations, as she by will may think proper," held a trust for the relations.

Bernard v. Minshall (1859), Johns. 276, 28 L. J. Ch. 649. "If I find it purposely left to the donee of the property to select the object in any manner he may think proper, then that is of course strong evidence to show that what was expressed by way of wish was not intended by way of trust, but was left absolutely to the sole discretion and control of the donee. But if $I$ find that an absolute object was intended with reference to the property in question, although that object may fail to be ascertained, yet, once admit there is a definite object, and a trust is the clear result." Per Wood, V. C., holding no trust arose from the words: "It is my request that he dispose" as he may deem most desirable to carry out my wishes after expressed to him.

Butier v. Gray (1869), I. R. 5 Ch. App. 26, 39 I. J. Ch. 291, I8 W. R. 193, was a bequest of residue "to be equally divided, share and share alike among all my children who are now or were then living. $M_{y}$ will is that a trust fund be formed as soon as possible, and invest the money as it comes in, * * the dividends for each of my chil. dren's own use during their respective lives, and if they have a child or children' born in wedlock then the principal to be at the disposal of the parent by will to such child or children," if no children then to the survivors. "This was held to give the children only life estates with gifts over to the grandchildren. .

Gray v. Gray (I860), II Ir. Ch. 218, was a gift by will of all property, real or personal, to two sons, "in the most absolute manner," one a lawyer, the other a doctor, who were also made executors; and without making any other gifts testator wrote, "I further will and hereby declare it to be my intention that said Moses and John shall at their discretion and according to their own judgment, allocate to the other members of my family, being my lawfully begotten children, such portions of the said property and goods, be the same more or less, as to them shall seem fit and suitable;" and Trevor, M. R., held a trust was manifestly intended, and if not validly defined the trustees could not claim beneficially, and for want of appointment division would be made equally.

Haly's Trusts (1889), 23 L. R. Ir. 130, A. C., was a bequest to sister E, for her sole and separate use "and to be appropriated by her to and amongst her children in such shares as she shall think proper," and, E having died before the testator, the court said it was not necessary to hold that her beneficial interest was for life only, but that her children took the whole sum by implication.

Gilbert v. Chapin (1848), Ig Conn. 343, was a devise to wife "to her and her heirs forever, recommending her to give the same to my children," \&c. She married and devised it to the children as recommended, but the court held she had an absolute fee, not subject to any trust; wherefore her husband was entitled to curtesy. 
3. Where Property is Given in Trust With Power to appoint to a class, and the trustee fails to appoint, equity impresses the trust on the estate for the benefit of the objects as the trustee should have done, instead of giving effect to an estate implied to the objects from the words of the instrument giving the power, as would be done if the donee of the power did not hold the legal title to the estate to be appointed. ${ }^{6}$

- Property Given in Trust With Power to Appoint.

Power in Trust Defined by Prof. Gray: "If a legal life estate is given to A, with a power of appointment, the gift implied in default of appointment will be a legal estate. On the other hand, if an estate is given to trustees, and a power is given to $A$ to appoint, the gift implied in default of appointment will be of an equitable estate only; but this is not because the power itself is in trust, but because the subject of the power is only an equitable interest. In cases of this second kind if $A$ is both owner of the legal estate as trustee, and also donee of the power, there is in default of appointment undoubtedly a trust on his legal estate for the objects of the power; and therefore it is fair enough to say that $A$ has a power in trust, because a trust is fastened on his estate by reason of the existence of the power. This is what occurred in the earlier case- in which the expression 'power in trust' was used. Such was the case of Brown v. I. ggs (1799), 4 Ves. 708, 5 Ves. 495 (1800), 8 Ves. 561 (1803)." 25 Harv. I. Rev. 3.

Perry on Trusts (6th Ed.), \& 255. "Generally, if the power is left unexecuted by the donee, the court will execute it as a trust by dividing the fund equally among the objects." Quoted, Wetmore v. Henry (I913), 259 Ill. 80, 84, I02 N. E. I89, a case of devise to a trustee.

Who has the Power, whether the trustees, a life beneficiasy, or a stranger, is immaterial if the property is certainly given in trust. Burrough v. Philcox (1840), 5 Mylne \& Cr. $73,95,5$ Jur. 453 .

In Ahearne v. Aherne (1881), g I. R. Ir. I44, was an action to interpret the will by which testator gave everything to his son and daughter equally and absolutely in the first instance and then added that the gifts to the daughter were for life with power to appoint among her children. The court held there was a trust for the children; and that the-daughter could not make her title absolute by not exercising the power.

Moore v. Ffolliot (1887), 19 L. R. Ir. 499, 5 Gray Cas. (2nd Ed.) 352, was a gift by will of all property to three nieces during their joint and several lives, but "in leaving my property to my three nieces as coheirs. it is my wish that if my nephew James conducts himself to their satisfaction they shall leave him the property I now leave to them." James and two of the nieces being dead testator's heir claimed the real estate, no appointment having been made. Porter, M. R., held that the heir was entitled, because the donees of the power had but a life estate which would not be affected by the appointment; and in such cases a clear expression of desire of the donor in favor of the person or class merely implied a gift in the instrument giving the power, and did not create a trust in their favor as would be the case if the legal title of the estate to be affected were given to the donee of the power as trustee. He said a gift implied from a power to appoint (this case) was only such estate as could be appointed and the beneficiary being dead none could be appointed. Several cases are reviewed.

Bull v. Bull ( 1830$), 8$ Conn. 47 , decreeing distribution among "brothers and sisters and their children most in need of same," trustees being dead.

Faton v. Eaton (I914), 88 Conn. 26g, 9r Atl. 19r, pras a devise to trustees directed to pay to children, and declared to impart a gift to the children on suit by the trustees for instructions, as to rights of illegitimates, etc.

Dunn จ. Morse (I9I2), 109 Me. 254, 83 Atl. 795, direction to trustees to give to charity.

Portsmouth v. Shackford (1866), 46 N. H. 423 , in trust for the benefit of brothers and sisters. 
Whether the Court will Exercise the Discretion given the trustee is not agreed. In some cases the courts have inquired who are the needy relations among whom testator directed division, declaring that to be a fact which the court can ascertain as well as the trustee. ${ }^{\text {? }}$ But the general rule is that the courts make equal division on the maxim that equality is equity. 8

People v. Power (1895), I47 N. Y. 104, 4 I N. E. 432, dictum, the trust to appoint 8 charity being in this case roid for uncertainty.

Cathey v. Cathey (1848), 9 Humph. (28 Tenn.) 470, 49 Am. Dec. 714, "We think that by the will of James Cathey his children took a vested interest in his estate immediately upon his death. He gives his property to his wife, for her to divide among his children, as she may think best. This is in fact a gift to his children in such propor. tions and so distributed as their mother might think best, but still it must go to his children. No one else can take, and no one of them can be excluded." Held, that the cstate of a child who died before the mother was not divested, she having made no appointment.

Jones's Estate ( 1893 ), 84 Wis. 465, 54 N. W. 917 , "I will and direct" my wife and executor to devise two-thirds of my estate to my nearest relations as will look reasonable to her.

Sawtelle จ. Witham (1896), 94 Wis. 412, 69 N. W. 72, gift to trustees for charity who refuse to take trust.

$\checkmark$ Discretion of Trustee Exercised by Court.

Gower v. Manwaring (1750), 2 Ves. Sr. 87 and 210 , is a leading case. It was a deed in trust by which the trustees were direeted to give the residue among his friends and relations where they should see most need. Two trustees being dead the court was asked to distribute. Hardwicke, C., said: "Where trustees have power to distribute generally, eccording to their discretion, without any object pointed out or rule laid down, the court interposes not, unless in case of charity, which is different, the court exercising 2 discretion as having the general government and regulation of charity. But here is a rule laid down. - - The trustees are to judge on the necessity and occasion of the family. That is a judgment to be made on facts existing, so that the court can make the judgment as well as the trustees."

Hewett v. Hewett $(x 764), 2$ Eden $330^{\circ}$, in which the chancellor superviged the cutting of timber by the life tenant, when fit, as the trustee was to do.

Maberly v. Turton (1808), 34 Ves. 499, was a direction by Lord Eldon, C., to 2 master to inquire whether it would be reasonable "at the discretion" of the trustee to apply interest to maintenance of children.

Iiley v. Hey (1842), I Hare 580, was a devise to incompetent trustees to distribute the rents annually among the families of twenty-four named persons "according to their circumstances;" the vice chancellor direeted inquiry to determine the necessities of each.

Bull v. Bull ( 1830 ), 8 Conn. 47 , holding the court will determine the most "needy" though it would not attempt to decide who is "most worthy" or "most deserving."

- Discretion Not Exercised by Court.

Maddison v. Andrew (1747), I Ves. Sr. 57, was a bequest of $£ 600$ to widow. and executrix to dispose among their daughters, as she should think fit. Her appointment was roid because exclusive; it was claimed that the pidow's discretion devolved on the court, which ought to apportion most to those who had been given no share, so as to make all equal. The court said: "It is true that powers have devolved on the court by non-acting, misbehaving, or death of trustees, as in appointing maintenance, it being a necessary thing. * But this is a peculiar kind of parental discretion with which the court has nothing to do."

Longmore v. Broom (1802), 7 Ves. 124, was upon trust to the executors to pay among $J, B$, and $H$, or their children. Sir Wm. Grant, M. R., said: "The executors then having their discretion might say to whom the fund should be given, the parents, 


\section{While the Trustee Continues to Act the court will not control his} discretion in the absence of fraud. ${ }^{\circ}$

or the children. But the court has not that discretion; but has only to say what class shall take, and then the distribution must be equal."

Keates v. Burton (I808), I4 Ves. 434, was a power to executors to pay 22000 to $J$, or if more to his advantage, to invest it for his benefit. Sir Wm. Grant, M. R., said: "This is not such a power as the court would take upon itself to execute; and if it wers, what circumstances are there authorizing me to say that it is more to the advantage of the man to take the interest than the principal."

Lancaster v. Lancaster (1847), I De G. \& Sin. 288, I7 I. J. Ch. 270, affirmed ( 1848 ), 2 Phillips 657 , was a devise to trustees to maintain $S$ till 25 , or married, then to settle such part as they deem proper on her for life, remainder to her children, if any, and if none, to her in fee, the rest to testator's heir. S attained 25, died unmarried, and the court held there was no trust her heir could enforce, but a mere power now expired and a manifest intent to benefit her personally.

Tweedale v. Tweedale $(1878), 7$ Ch. D. 633,47 L. J. Ch. 530, 38 I. T. 137,26 W. R. 457, "I am clearly of opinion that whatever the rights of the trustees to exercise discretion [as to the amount of the advances] in this case originally were, in the events which happened, that discretion was done away with." Per Malins, V. C.

Wetmore v. Henry (Igr3), 259 III. 80, 102 N. E. 189, "as he in his discretion shall deem each of them worthy," distributed equally.

McGaughey v. Henry ( 1854 ), $54 \mathrm{Ky}$., I5 B. Mon. 383, 398, "the chancellor, if he recognizes the right at all, recognizes it as belonging to a class from which the selection or discrimination is to be made, and divides it among them equally, per capita."

Portsmouth v. Shackford ( 1866$), 46 \mathrm{~N}$. H. 423, "the court in making distribution of the fund will ordinarily be governed by the statute of distributions."

- While Trustee Continues to Act.

Mosely v. Mosely (1673), Finch Ch. 53, was a power to executors to nominate one of the nephews, and the chancellor ordered the executors to agree in two weeks o- he would himself nominate.

Clark v. Turner $(1694), 2$ Freem. Ch. I98, was a devise to a trustee in fee to convey to such of testator's relations as he should think best and most reputable, and the chancellor ordered the trustee to convey to testator's brother who was his heir at law, because most reputable for the family though testator had said he was a bad husband. Now courts disclaim to exercise such powers. Kemp v. Kemp (1795-1801), 5 Ves. 849, 858 , reviewing other cases.

Tabor v. Brooks (1878), to Ch. D. 273, 48 L. J. Ch. I30, 39 L. T. 528, was an attempt to compel trustees under a marriage settlement with power to apply the income for the benefit of the husband, wife and children in their "irresistible discretion" to pay some part to the wife living apart from the husband because he was a drunkard; but the court refused to interfere with their attempt to make her live with him by paying him the whole income.

In re Lofthouse (1885), 29 Ch. D. 921,54 I. J. Ch. 1087, 53 I. T. 174, 33 W. R. 668-A. C., was an attempt to compel trustees to make a substantial allowance for support of an infant, under the clause of a will: "I empower the trustees or trustee for the time being to apply all or any part of the yearly income of the share or shares to which each or any infant shall be entitled" too towards maintenance; and the order made in the court below because the refusal was perverse was reversed on appeal.

Van Brocklin's Estate (1888), 74 Iowa 412, 38 N. W. Ir9, was a devise to executors to sell, who accepted but refused to sell and divide, and on suit to compel a sale the court held the executors had a discretion as to when to sell which the court would not control.

Drew v. Wakefield ( 1865 ), 54 Me. 29r, 299, "trustees if willing to act will not on bill being filed for carrying the trust into execution, be deprived of their discretionary power," in this case to chose "deserving relations," \&c.

Portsmouth v. Shackford (I866), 46 N. H. 423, 426, "If the power of selection be given the court will not interfere with its exercise by the trustee so long as its exercise 
Whether the Power itself may be in Trust without the trustee having title to any estate on which exercise of the power would operate seems not entirely clear. To call a power which the holder is under no duty to exercise a trust is a misnomer, as trusts are always mandatory. If the settlor in effect directs that the power be exercised, that is in substance an express gift to the object. ${ }^{10}$

is governed by sound discretion." In this case "for the benefit and comfort of my brothers and sisters." The court refused to order the trustees to support a pauper sister at the suit of the city.

Read v. Patterson (1888), 44 N. J. Eq. 2II, I4 Atl. 490, (court of errors), was a seversal of a decree in a suit to compel trustees to make allowance, the court saying: "A court of equity will examine into the conduct of a trastee in the execution of his dis. cretionary powers. " * But the court will exercise this prerogative with great caution, and will not displace the trustee from exercising his functions unless * " it appears that he has abused his trust."

In McDonald $\nabla$. O'Hara (1894), 9 Misc. 686, 30 N. Y. Supp. 545, affirmed without opinion, I44 N. Y. 642, 39 N. E. 642, objection by some of the beneficiaries to a proposed sale by executors under a power, on the ground that the time was unfarorable was held no reason for interference.

10 Power Only as Subject of Trust.

If the Donee of the Power Has no Estate. Prof. Gray says: "The donee may have no estate or interest in the property, as when property is given to A for life, with a power to $B$ to appoint the remainder, this is calkd a power simply collateral. Is. such a power ever a power in trust? A system of law is conceivable in which equity would compel a donee to exercise such a power or would exercise it for him. In such a system a power of this kind might be properly called a power in trust. But such is not the system of our law. When our law thinks that the objects of a power ought to have an estate or interest in property, although no appointment has been made, it does not compel the donee to exercise the power, nor does it exercise it for him, but it declares that there is an implied gift to the objects of the power in default of appointment. Sometimes the implied gift is of a legal, sometimes of an equitable estate or

- interest. * - [That the property in the cases in which donee of the power has no estate] passes by implied gift and not by an exercise. of the power appears from several considerations: 1. Equity never compels a donee to exercise a power, what it does is to act when he has not exercised it. 2. When a legal estate is given to $A$ for life and $a$ power is given to $A$ or $B$ to appoint the remainder, if the objects of the power take in default of appointment they must take by an implied gift; equity has nothing to do with it. (See Morgan v. Surman (1808), I Taunt. 289; Halfhead v. Sheppard (1859), I E. \& E. 918; Tomlinson v. Nickell (1884), 24 W. Va. 148; McGaughey v. Henry (1854), I5 B. Mon. 383; Rogers v. Rogers (1859), 2 Head (Tenn.) 660). 3. The case of Bull v. Vardy (I79I), I Ves. Jr. 270, is conclusive to the point that equity does not exercise a power when there is a failure to appoint. " * 4. If equity really exercised an exclusive discretionary power, it would exercise the full power, discretion and all. This it never does. The estate or interest which is to arise in default of appointment is determined by fixed rules into which no element of discretion enters. * * 5. If equity really exercised the power when the donee failed to exercise it, there is no reason why it should not aid the non-execution of a power in a case where it would aid a defective execution. But it is an immutable rule that a non-execution shall never be aided. It cannot be denied that in many of the cases, especially the earlier ones, the objects of a power are said to take because the power is in trust, but the distinction between the exercise of a power and an implied gift does not appear to have been in the minds of the courts. Even down to recent times we find a trust coupled with 2 power and a gift by implication spoken of as if they were the same thing. It was the acute mind of Lord St. Leonards which first perceived that when the objects of a 


\section{- 4. Where no Trust nor Gift Manifestly INTENDED-Mere:} POWER.

a. GENERAL POWER. No gift is ever implied in default of exercise of a mere power under which the donee might appoint to anyone he pleased including himself. There is too much uncertainty. A

power take upon failure to appoint, they take by an implied gift." 25 . Harvard I. Rev. 2-7.

Sugden says: "We must be careful to distinguish between mere powers, and powers in the nature of trusts. The distinction between a power and a trust is marked and obvious. 'Powers,' as Wilmot, C. T., observed (Wilm. 23), 'are never imperative; they leave the act to be done at the will of the party to whom they are given. Trusts are always imperative, and are obligatory upon the conscience of the party intrusted.' But sometimes trusts and powers are blended; a man may be invested with a trust to be effected by the execution of a power given to him, which is in that case imperative; and if he refuse to execute it, or die without having executed it, equity, on the general sule that the trust is the land, will carry the trust into execution at the expense of the remainderman, and without any regard to the person in whose favor it is to be executed being a mere volunteer, and not a purchaser, creditor, wife, or child. This is the case where a power is given by a will to trustees to sell an estate and apply the money ron trusts. The power is in the nature of a trust. The legal estate, until the execution of the power, of course descends to the heir at law; and if the power be defeated at law by the death of the person to whom it was given, the legal estate would remain in the heir at law for his own benefit; but equity, acting upon the trust, will compel the heir to join in the sale of the estate for the purposes designated by the testator." Powers, c. $I x, 86$, pl. 3 .

Garfoot v. Garfoot (1663), I Chan. Cas. 35, "Lands were devised to the former for life, afterwards to be sold by the executor for younger children's portions; the executor dies, the younger children prefer their bill against the heir, he demurs because but an authority to the executor which is dead with them; but the demurrer was overruled." The above is the entire report.

Cruwys v. Colman (1804), 9 Ves. 3rg, declaring a gift to sister for life "and it is my absolute desire" that she bequeath it to her own family, creates a trust, being sufficient words, certain subject and definite object.

Grieveson $\vee$. Kirsopp $(2838), 2$ Keen. 653 , involved a power to widow to sell with assistance of the trustees, with power to her to divide among his children as she should think fit. She did not sell nor make any valid appointment. Shadwell, V. C., said: "I am, therefore, of opinion that the power was in the nature of a trust for the children, and that subject to such appointment as she might have made, the children were entitied in equal shares. * * It further appears to me that the direction to sell, expressed as it is, operated as a conversion of the real estate."

In Burrough v. Philcox $(1840), 5$ Mylne \& Co. 73 , the chancellor says that "in such cases the court will not permit the objects of the power to suffer by the negligent conduct of the donee but fastens upon the property a trust for their benefit."

Brook v. Brook ( 1856$)$, $3 \mathrm{Sm}$. \& Giff. 280, holds a devise of copyhold to Mary (undefined) to her separate use, "with power to appoint" to her husband and children to be a gift in fee to Mary and no trust or gift to husband or children.

Greenough v. Welles (1852), 88 Mass. (10 Cush.) 57r, was: "All my estate that I have not disposed of I order to be sold by my executor and the proceeds divided between my two daughters;" and it was contended that by the executor being embraced in the confiscation act of 1779 , and fleeing from the country, and appointment of admin. istrators in his place, the title which had descended to testator's heirs subject to the power and duty of the executor to sell had become indefeasible; but the court held the land was still subject to the trust in the hands of the heir and ordered conveyance by them, saying, "equity acting upon the trust will compel the heir to join in the sale." 578

MeGaughey v. Henry (1854), $54 \mathrm{Ky}$. (I5 B. Mon.) 383, speaks of the power as .2 trust, and bases right of children thereon. 
gift to the whole world could not be implied."I If the donee of the general power authorizes another to make the appointment to specified persons the giving of this special power is an exercise of the

Loosing v. Loosing (Ig09), 85 Neb. 66, 122 N. W. 707, 25 L. R. A. N. S. 920, recognizes a power as subject of a trust.

Philadelphia's Appeal (1886), I12 Pa. 470, 4 Atl. 4, holds a desire expressed in the will that land be sold and the proceeds invested, etc., is an equitable conversion, leaving the executor no discretion.

By Statute. In New York, Michigan, Wisconsin, Minnesota, etc., "every trust power, unless its execution or non-execution is made expressly to depend on the will of the grantee, is imperative, and imposes a duty on the grantee, the performance of which will be compelled in equity, for the benefit of the parties interested." These statutes are construed as applying though no title to the property is given to the donee of the power. "In all these cases the permission imports a power, the power implies a trust, and the trust imposes a duty." In this case the court overruled a demurrer by the heir to the bill filed by the object of the power to quiet title, the power never being exercised. Smith v. Floyd (I893), I40 N. Y. 337, 35 N. E. 606. See also Dominick $\nabla$. Sayer (I850) 3 Sandf. Ch. (N. Y.) 555 .

Matter. of Gantert (1892), 136 N. Y. 106, 32 N. E. 55I, decides that a direction to pay debts and a separate clause in the will authorizing the executor to sell without limiting the purpose, entitle a creditor to an order compelling the executor to sell to pay debts, there being no sufficient personalty.

Venable v. Mercantile Trust Co. (1891), 74 Md. 187, 2I Atl. 704, was a suit to try the right of an administrator c. $t$. a: to sell under a statute giving such officer the powers given to executors, and a will directing division with power to the executor to sell for that purpose. The court held that the administrator c. $t$. a. could sell.

Jones v. Roberts (1893), 84 Wis. 473, 54 N. W. 917. Derse v. Derse (1899), 103 Wis. $113,79 \mathrm{~N}$. W. 44 , ordering division equally among children of property widow conveyed to one, she having "full and sole control to devise and bequeath the same to the several members of my family in shares as she may see fit." The statute provided "if the trustee of a power with right of selection shall die leaving the power unexecuted, its execution shall be adjudged in the circuit court for the benefit equally of all the persons designated as objects of the trust."

11 General Powers Not Exercised.

Equity will not aid non-execution of such 2 power, even in favor of a creditor. Holmes v. Coghill (1802), 7 Ves. 499, 28 Eng. Rul. Cas. 577, 5 Gray Cas. (2nd Ed.) 390. Then they have no rights at law. Brandies v. Cochrane (1884), II2 U. S. 352, 5 S. Ct. 194.

For a volunteer the court will not aid non-execution or defective execution, though the donee has manifested an intention to execute. Pigott v. Pinrice (1717), Finch Prec. Ch. 47I, 2 Eq. Cas. Abr. I9I, pl. 6; Gilb. Eq. 137, Com. 250, 5 Gray Cas. (2nd Ed.) 406.

It is against the nature of a power that the court should do what the party has reserved or had granted to him the power to leave not done. Tomkin $\nabla$. Sandys, 2 P. Wms. 228n. Sugden, Powers, c. II, $\$ 6$, pl. 2.

A covenant with $A$ to pay $£ 20$ to such person as $A$ shall appoint was held not to enable $A$ 's executor to sue the covenantor for the amount when $A$ died without appointing, though the executor is A's successor and assignee in law; for hers by the terms of the obligation, the covenantee is only bound to pay someone expressly designated by $A$; he is only liable according to the terms of his covenant. Pease v. Mead (1613), Hobart 9, Godbolt 192, I Brownl. \& G. 77.

Supreme Colong v. Towne (1914), 87 Conn. 644, 89 Atl. 264, Ann. Cas. I9I6D, I8I, was a bill of interpleader by a fraternal society to determone who was entitled to the amount of a life insurance on deceased which he had power to appoint to whom he pleased, and on which he had named his wife as beneficiary. She died before him. He named no other beneficiary, the rules of the society made no provision for such a case; and the court held that neither the administrator of the insured nor ary one else had 
general power, and from the special power so given a gift by way of appointment may be implied to the person specified in default of appointment under the special power.12.

b. Special Powers. Certainty. The same difficulty of uncertainty may arise under a special power. ${ }^{13}$

any action against the society for the money. In the note to the last report numerous cases to the same effect are collected.

Iyon v. Safe Deposit \& Trust Co. (1913), $320 \mathrm{Md}$. 514, 532, 87 Atl. 2089.

Harrison v. Battle (1835), 21 N. C. (I Dev. \& B. Eq.) 213, was a deed of transfer of a slave and her increase to a trustee to the use of $F$ for life, and at her death to transfer the slave and increase to such person as $F$ should direct. $F$ died without making any appointment, and on bill of interpleader by the trustee against the administrators of $F$ and her husband, it was held neither was entitled, as $F$ had no estate beyond her life, and the court could not supply a non-execution.

Higginson v. Kerr (1898), 30 Ont. Rep. 62, holds power to executors to dispose of the residue "where they may consider it will do the most good" under which they might appoint to themselves implied no trust or gift to anyone.

If a lawyer advises the donee of the power that she owns in fee, and because of such advice she neglects to execute the power; still the court would not aid the ronexecution even in favor of her children. Mitchell v. Denson (1856), 29 Ala. 327, 65 Am. Dee. 403.

Liens and Equities of Third Parties. Testator devised his farm to his widow and daughters for life, then to the church, with power to them to sell for support if income were insufficient. One daughter waived to her mother and sister all share if income were insufficient. One dar support, and after the death of the others asked the court to sell to make back what she had advanced. The court held that whatever the court to sell to make back what she on the estates of the deceased, and however beneficial her waiver was to the remainderman, the power was expired, and the court could not subject the property to any charge because of the advances. Hare v. Congregational Soc. (1904), 76 Vt. 362,57 Atl. 964 .

Ryan v. Mahon (1898), 20 R. I. 417, 39 Atl. 893, was a bill by one who had supplied funds to support the donee of the power to sell for support, never exercised, to have benefit of the power for reimbursement; and it was held that he was without remedy as the power was personal and died with the donee.

"I order my executors to sell so much as may be necessary for their support," is not a mere power but a trust, and creditors who have furnished the support have a right to demand sale if the trustees fail to make it. Cutter v. Burroughs (1905), 100 Me. 379,61 At1. 767 .

"Relations or Friends." Chapin's Will (r865), 2 Dr. \& Sm. 527, 34 L. J. Ch. 578, 12 I. T. 526 , 13 W. R. 646 , holds that a power to appoint to "relations. or friends" is $12 \mathrm{~L}$. T. 526,13 . next of kin take by gift implied, citing Gower v. Manwaring (1750), 2 Ves. Sr. 86, which holds that direction to trustees to divide among "friends and relations" must be interpreted next of kin.

12 Gift Implied from Special Power Given under General Power.

White v. Wilson (1852), I Drury 298, 22 I. J. Ch. 62, 17 Jur. 15, I W. R. 47. In this case, a married woman having power by will to appoint $\varepsilon_{13}, 000$ to whom she pleased after the trust in it to her separate use for life, she appointed part of it to named persons, and the rest as her husband should appoint to her children or their executors. The husband attempted to make an exclusive appointment, which was held void; but the court held the children took by implication from their mother's will.

12 Uneertainty Preventing Implication from Special Powers.

"I am of opinion that there is an intestacy in this case. * No less than four implied gifts have been suggested: $I$, that there is an implied gift in favor of the other children excluding James; 2 , that there is an implied gift to James excluding the 
Power to Appoint to a Charity not fully defined has been held sufficient to imply such a gift in default of appointment.14

Uncertainty as to the Amount to be appointed has been held not to prevent implication of a gift in default of appointment, a gift

other children; 3 , that it is an implied gift to all including James; and, 4, that the implied gift is' of one-half to James and the other half to the other children. * In this case it is not simply a power to pay over the money to the children of $A$ or the children of $B$, but it is at the discretion of the trustees to apply the whole or such part as they think fit of the capital or income or both, for the personal maintenance and support, or otherwise for the benefit of James, or otherwise at the option of the trustees, to apply the whole or such part thereof in augmentation of the shares of the other children of the testator. And how can I from the terms of this power draw any inference as to the persons to whom or the shares in which the testator meant the property to $g \circ$ in default of exercise of the power. I confess I think that about as much weight is to be attributed to the argument for all the children, excluding James, as to that in favor of James excluding the others, or as to that in favor of all equally." In re Eddowes (286r), I Dr. \& Sm. 395, 7 Jur. N. S. 354, per Kindersley, V. C.

In White's Trusts ( 1860 ), Johns. 656, testator declared that in the event which happened, "I confide in the said trustees for applying the said last mentioned sum of $£ 2,500$ capital stock to the benefit of such other of my children or their issue as they may see fit, for the interest and good of my family;" and to the contention that the intended benefit failed for uncertainty on default of the trustees, Wood, V. C., said, Bagley v. Mullard (1830), I R. \& My. 58I, is conclusive against that view.

Elliot $\nabla$. Hele (1688), I Vern. 406, tenant in tail with general power covenants in consideration of marriage to jointure and not said what or how much. He does not make jointure, his wife dies, and her representative claims jointure from estate settled by remainderman on his marriage. Bill dismissed because of uncertainty as to jointure and want of equity of representative against wife of remainderman.

It To Charity.

Doyley v. Atty. Gen. (1735), 4 Vin. Abr. 485, pl. I6, was 2 gift to trustees with direction in default of issue to divide among such relations as they thought fit, and for "such charitable uses as they should think most proper and convenient;" and division was made half to the relations and half to charity.

Down v. Worsall (1833), I Mylne \& K. 56r, was a bequest of residue to execiutors in trust "to settle such part thereof either to or for charitable or pious purposes at their discretion, or otherwise for the sperate benefit of my sister, independent of her husband, and all or any of her children." The trustees having died without executing the trust, Ireach, M. R., said: "Where a disposition is made in favor of a charity and the trustee fails, the court will interfere and execute the trust; but here no disposition is made in favor of charity as to the unappointed part. The trustees had a personal discretion as to the application of the fund; and as they bave died without exercising that discretion, this part of the property is undisposed of by the testator and belongs to the next of kin." It is submitted the decision is wrong.

Salusbury v. Denton (1857), 3 Kay \& J. 529, 26 I. J. Ch. 851, 3 Jur. N. S. 740, 5 W. R. 865 , was a bequest of residue insurance as to moiety "at the disposal by her will * * to apply part to the foundation of a charity school, or such other charitable endowment for the benefit of the poor of Offey as she may prefer * * , and the remainder of said moiety to be at her disposal among my relatives," and in default of appointment the gift was held not roid for uncertainty, and distribution was ordered half to charity and half to the next of kin.

Hunter v. Atty. Gen. I. R. (1899), App. Cas. 309, 68 I. J. Ch. 449, 80 I. T. 732, .47 W. R." $673,-$ II L "It is undoubtedly the law that where a bequest is made for a charitable purpose and also for an indefinite purpose not charitable, and no appointment is made by the will, so that the whole might be applied for either purpose, the 
being implied of the full amount of the fund which the donee of the power might have appointed.15

Generally a mere power to appoint to individuals or members of a certain class raises an implied gift to the possible beneficiaries of

whole bequest is void." Per Halsbury, I. C., in holding void a power to trustees to invest any part of the residue (income or principal) they chose (I) to purchase advowsons, (2) endow churches, schools, or chapels, (3) pay salaries of teachers, sectors or vicars, the last two charitable, the first not necessarily so.

People v. Powers (1895), I47 N. Y. 104, 4I N. E. 432, was a bequest to $P$ upon trust "that he will dispose of the property among the charitable and benevolent institutions or corporations in the city of Rochester;" and it was held unenforcible at the suit of such a charity, because void for uncertainty.

15 Uncertain Amount.

Wheeler v. Warner (I823), I Sim. \& Stu. 304, was a power to trustees to advance so the husband of his daughter, if married with their consent, a part of her fortune, they having discretion as to the amount, and Sir John Leach, V. C., held this equivalent to a gift to the husband of all the trustees had power to appoint, the marriage having occurred in the testator's lifetime with his assent.

I ancashire v. Lancashire (I847), I DeG. \& Sm. 289, affirmed 2 Phillips 65: I7 L. J. Ch. 270 , I2 Jur. 363 , was a devise to trustees to maintain $S$ till 25 or married with consent, then to settle such part as they should deem proper to her separate use for life remainder to her children, if any; if none, to her in fee. $S$ attained 25 , died unmarried, and her heir claimed the estate. No point was made of the uncertainty but Cottenham, C., held there was no trust, but a mere power and a manifest intent to benefit her personally, wherefore testator's heir was entitled to all.

Bradley v. Cartwright (1867), I. R. 2, P. C. 511,36 I. J. C. P. 218 , I6 I. T. 587, I5 W. R. 922, was a devise to $S$ for life, then to trustees to support contingent ises, then to all issue of $\mathbf{S}$ as he should appoint, and in default of issue to testator's other sons. It was contended that $S$ took an estate tail by the gift to him for life, the power and the gift over in default of issue, but the court held the gift implied to the issue was a fee, not an estate tail, because he had power to appoint to them in fee, wherefore S took but a life estate.

Tweedale v. Tweedale ( 1878 ), 7 Ch. D. 633,47 Ir. J. Ch. 530, 38 I. T. I37, 26 W. R. 457, was an authority to trustees to grant to the husband of any daughter marry. ing with their consent, such part or the whole of the annual produce of the daughter's share as they should think proper, and Malins, V. C, held, following Wheeler v. Warner, I S. \& S. 304, that the husband took by implication the income on the full amount of the datughter's share.

Gray v. Gray (1860), II Ir. Ch. 218, was a devise of everything to two sons "in the most absolute manner" and that these sons "shall at their discretion and according to their own judgment allocate to the other members of my family" * * "such portions of the said property and goods as to them shall seem fit and suitable," and it was held that if the uncertainty in the amount prevented a valid trust for the other children, the manifest intent that the two sons were "to act as trustees prevented them from taking beneficially.

Haly's Trust (1889), 23 L. R. Ir. 130, was a legacy of $£ 2,000$ to sister $\mathrm{E}$ for her separate use "and to be appropriated by her to and amongst her children in such shares as she shall think proper." E died before testator but it was held that her children took by implication, though $\mathbf{E}$ would have had a beneficial interest had she survived.

Dunn v. Morse (1912), I09 Me. 254, 83 Atl. 795, was a power to trustees to nominate needy relations to such amounts as the trustees deem advisable, and the rest to charity, and in default of appointment the court thought there was an intent to permit the trustees to appoint or let all go to charity, so that the relations took nothing if not appointed and all went to charity.

See also Hunter v. Atty. Gen. (I899), I. R. App. Cas. 309-H. E., above quoted. 
the power in default of appointment, ${ }^{16}$ unless the context shows that the testator did not intend it. 17

16 General Rule That Gift is Implied from Special Power.

Kennedy v. Kingston (I82r), 2 Jac. \& W. 43I, 2 Gray Cas. (2nd Ed.) 337, is one of the first cases putting the gift to the children in default of appointment on the ground of implied gift. It was a power by will to $A$. to appoint at her death to her children the $\sum_{500}$ given to her for life. She appointed half to one daughter (who later died before her) and the rest to the others. The court held that as the power was to be exercised only at death, those only could be appointed who survived the donee of the power, and the gift implied was confined to them also. "The power, therefore, must be understood as tacitly including a provision for an equal division of the fund amongst the objects, in the event of no appointment being made."

Brown v. Pocock (1833), 6 Simons 257, was a bequest of a fund to produce £2 $a$ week for $A$ for life, with power to $A$ to leave the fund to his wife and children. Two children were born after testator died, and the wife and one child died before $A$, who made no valid appointment; and it was held the survivors took all as joint tenants.

Burrough v. Philcox (1840), 5 Mylne \& Cr. 73, 5 Jur. 453, was that if testator's children both die without children the survivor "shall have power by will" to appoint to any or among "my nephews and nieces or their children" the property given to trustees till these contingencies happen. The children had no issue, did not appoint, and tried to divert the property to others. Cottenham, C., held, on a bill to construe the will and execute the trusts, that the nephews and nieces took, saying: "When there appears a general intention in favor of a class, and a particular intention in favor of individuals of a class to be selected by another person, and the particular intention fails from that selection not being made, the court fill carry into effect the general intention in favor of the class. When stich an intention appears, the ease arises, as stated by I rord Eldon in Brown v. Higgs, 8 Ves. 574, of a power being so given as to make it a duty of the donee to execute it; and in such case the court will not permit the objects of the power to suffer by the neglect of the donee, but fastens upon the property a trust for their benefit."

McGaughey จ. Henry (1854), 54 Ky. (I5 B. Mon.) 383 , devise to wife to divide "among such children as she please" not executed.

Loosing v. L,oosing (1909), 85 Neb. 66, 122 N. W. 707, 25 I. R. A. N. S. 920, was, "I want my wife to dispose or distribute this property which I have not devised, as she sees fit. * * The remaining children which I have not mentioned in this will, I-leave it to my wife to give them as she sees fit out of the property I left for her to dispose of." Held an implied gift.

Smith v. Floyd (1893), I40 N. Y. 337, 35 N. F. 606, was a will of estate to son and daughter about equally, for life, with power in the son to appoint his children, and gift over to the daughter if he died without children. He left children but did not exercise the power. The children took. Wilson $\nabla$. Van Epps (1902), 38 N. Y. Misc. 486, "privilege" to appoint "heirs."

Cruise v. McKee (1858), 39 Tenn. (2 Head) r, 73 Am. Dec. 186; Rogers v. Rogers (1859), 39 Tenn. (2 Head.) 660 , the privilege of giving as she pleased among her children or grandchildren.

Withers v. Yeadon (1845), I Rich. Eq. (S. C.) 324, 33I; Atkinson v. Dowling (1890), 33 S. C. 414,12 S. E. 93 , dictum.

M'Camant v. Nuckolls (1888), 85 Va. 331, 12 S. F. I60, indicates that in Virginia there must be more than a power to appoint to a class to give rights to the possible appointees in case of default. The court indicates that it depends on the manifest intention.

Milhollen v. Rice (1878), I3 W. Va. 543, 565, "at her disposal to whom she thinks proper of her heirs."

That no Gift is Implied.

Duke of Marlborough $\nabla$. Godolphin (1750), 2 Ves. Sr, 61, was a bequest of $£_{30,000}$ to the wife to her own use for life only, and after her decease to be divided and dis- 
tributed to and amongst such of his children, and in such manner and proportion as she by any deed or will should appoint, and for no other purpose whatsoever. She appointed by will $£ 6,000$ to one, $£ 2,000$ to another, $£_{3}, 000$ to another, and the, remainder to two who died before her. The children who survived her, and the representa. tives of those who died claimed by direct gift from the original testator, Hardwicke, $C$., held first that the appointment could operate only as to those who survived the wife, since she intended only an appointment by will, though she could have appointed otherwise. He then continued on page 8I: "Which brings it to the next question, whether these sums will fall into the residue of the testator's personal estate, or accrue to his children? And whether it shall accrue to all his children and their representatives depends on the question at first considered, the construction of the clause in the codicil, viz. whether anything is given to the children eo nomine otherwise than by description of stich as she should appoint to, and consequently nothing to vest in them abstracted from her appointment. It would be very dificult to determine in what they should take, or how it would vest, if that was to be the case. The portions as well as the gift were to be settled by Lady Sunderland, who has given in her life several parts to several of them. What shares were to vest? Were they to take as joint tenants? That is denied by the representatives of the deceased children; because that would exclude them, and make it to the survivors. If to take as tenants in common, what are the shares? The settlement of the proportions and shares was to be by Lady Sunderland. None can take as tenants in common of uncertain, though they may of unequal she is; and if there was anything in this so as to make them take as children of the testator, I should incline that they should take as joint tenants, and consequentiy it should survive. No words of division or distribution are made use of by the testator but by way of reference to the division and distribution to be made by Lady Sunderland; so that it is part of her power only, and not distinct from her power, that imports a division between them as tenants in common. And how could it be? If all were to take this remaining $\sum_{I y, 000}$ equally in proportion among them as tenants in common, there would be unequal proportion thereby among them; for Irord Robert's share having $£ 6,000$ given him, would be made more, which would be contrary to the construction attempted on this. But 1 found myself on this that this is no gift to the children; and consequently the children cannot take it as such." This case is overruled.

Crossling v. Crossling ( 1794$), 2 \mathrm{Cox} \mathrm{Ch}$. 396, was a devise to the wife of testator for life, "and she shall dispose of the same amongst my children by her at her decease as she shall think proper." She made no disposition; the heir brought ejectment, and the other children sued in equity for injunction, insisting that the imperative command to dispose was a gift to the children; but the court held it was a mere power to the wife to appoint, and there was no instance of the heir being made trustee for objects of an unexecuted power. This case is overruled.

There are a few other cases in which it has been declared that there can be no gift implied from the power to appoint, but only from an intent manifest from the context. See: Week's Settlement $(1897)$, I Ch. D. 289 ; In re Hall (1899), I I. R. 308.

These cases are contrary to numerous prior decisions in the same courts, and it is submilted that they are wrong.

17 Context Rebutting Presumption.

Bull $\nabla$. Vardy (I79I), I Ves. Jr. 27r, was a devise of several houses to wife for life, without any interest in the produce of his general estate, followed by legacies to various persons on the death of his wife and sisters, then, "I further empower my wife to give away at her death $£_{1,000 ;} \mathcal{E}_{100}$ of it to Elizabeth Turner; $£_{100}$ to Mrs. Bennett; the other $£ 800$ to be disposed of by her will." The wife died without exercising the powers and on suit against her executor claiming the $\mathcal{E} 100$ to Elizabeth Turner, the barons of the exchequer agreed that the whole will made it obvious that the testator intended Elizabeth to take only in case the sum were appointed to her by the wife.

Carberry v. M'Carthy (I88I), 7 I. R. Ir. 328, was a gift to wife in trust to receive the income during her life with full power to dispose by deed or will to any of his children; but as the will declared that testator had already provided for his children, 
Naming the Individual to Take raises a stronger implication of gift than when the power is to appoint to a class. ${ }^{18}$

Power to Appoint the Whole Fund to Part of the Class does not prevent implication of a gift over to the class in default of appointment, ${ }^{10}$ unless it renders uncertain what gift is to be implied. ${ }^{20}$

$A$ P.over Only to Appoint One of a Class has been held not to imply a gift over to the class, because there was no power to appoint the whole class, and the court could not select one. But this qualification is very doubtful. ${ }^{21}$

wherefore he made no provision for them by his will, it was held that this expression refuted the presumption that otherwise would have arisen from the power of a gift to the children.

25 The Naming of the Individual.

"The naming of the individual no doubt strengthens the presumption of an intention to benefit, and thus renders the implication in his favor, in default of appointment, more plain; but when, as here, the implication undoubtedly arises, the ascertainment of the individual, however clear and definite, cannot aid us in determining what the extent of .the benefit is that is to be implied in his favor; and I see no solid distinction on this point between the present case and those of powers to appoint to a class." Moore v. Ffolliot (1887), 19 I. R. Ir. 499, 5 Gray Cas. (2nd Ed.) 352.

10 Power to Appoint All to Part of Class.

Witt v. Boddington (I790), 3 Bro. Ch. 94, Belt: "Among some one or more of the child or children."

Brown 7. Higgs (1799), 4 Ves, 704, (1803), 5 Ves. 495, (1803), 8 Ves. 561, was a bequest of leaseholds to $A$ to pay certain sums, and testator empowered him to employ the residue of the rents "to such children of my nephew Samuel Brown, as the said $A$ shall think most deserving, and that will make the best use of it, or to the children of another nephew if such there were or should be;" and in default of appointment this was considered a trust for all the children of both nephews. The decree of Irord Alvanley was confirmed by Iord EIdon on appeal, and again by the House of Ifords.

Burrough v. Philcox ( 1840 ), 5 Mylne \& Cr. 72, 5 Jur. 453.

McGaughey v. Henry (1854), 54 Ky. (I5 B. Mon.) 383, in which it was argued that no gift should be implied because it was a mere power.

20 In re Eddowes (286r), 2 Dr. \& Sm. 395, 7 Jur. n. s. 354, 5 I. T. 389, was a power to trustees with uncontrolled discretion to apply the whole or part of income or capital of $\sum_{1,000}$ out of the residue, as they saw fit, to maintain James, or to augment the shares of the other children; and it was contended on refusal of the trustees to appoint, that a gift was implied to James excluding the rest, to the rest excluding James, to all equally, or half to James and half to the rest, but Kindersley, V. C., felt unable to determine who should be the beneficiaries or their shares, and decreed intestacy as to that. See also the cases cited above as to uncertainty affecting the implied gift.

$\approx$ Power to Select One.

Brown v. Higgs (1799), 4 Ves. 708 is a leading authority of this class. One estate was devised "to one of the sons of my nephew Samuel Brown, as he shall direct by a conveyance in his lifetime or by his will." This point did not have to be decided; brat Iord Alvanley seemed to think it a mere power. What Lord Eldon thought is not very apparent.

The singular number "member of my family," does not necessarily mean onily one person. Sinnott v. Walsh ( 8880 ), 5 I. R. Ir. 27, 33, implying gift in default of appointment to all the children.

In Mosely v. Mosely (1673), Finch Ch. 53, the executors being nnable to agree which son to appoint, the chancellor ordered that unless they agree within a fortnight he would appoint, it being the testator's intent that his estate should not be divided but settled upon one. 
If the Power Never Asises the objects cannot take by gift implied from the power. ${ }^{22}$

An Express Gift over in Default of Appointment prevents implication of a gift to the class in default of appointment which would be inconsistent with the expressed gift over. ${ }^{28}$

Though the Express Gift over is Void the expression of that intent rebuts any presumption of an inconsistent implied gift over. ${ }^{24}$

Sugden says: "A power to give to such as a donee may select of a class may be considered as including the whole class for although any may be selected, yet the whole may be objects of the power; whereas a power to appoint to such one of a class as a person shall name, authorize a gift to one only of the class; no larger number, much less the whole class, can be made objects of the power. If, therefore, the power is in the nature of a trust, or there is a gift in the power itself by implication it can only be commensurate with the power, and therefore for one only of the objects. Which one would be the proper cestui que trust, or the person in whose favor the implied gift was made?" Sugden on Powers, (8th Ed.) c. II, 8 6, pl. 17.

2 If Power Never Arises.

So says Sugden, Powers, c. II, I6, 6 pl. (8th Ed.), citing Halfhead v. Shep' erd (I859), 5 Jur. N. S. II62, 28 L. J. (N. S.) Q. B. 248 , I E1. \& E. 918. This was a devise of all estates to wife for life, and ordered that after her death $R$, or if he died before her, she should divide it among testator's children as fairly as she could. All the children died in the lifetime of $R$ and the widow, and the court held that no estate vested in the children, because they died before the power could be exercised.

Moore v. Ffolliot (1887), 19 L. R. Ir. 499, 5 Gray Cas. (and Ed.) 352, was a gift of all property to three nieces for life with orders to leave it to $J$ at their death if he conducted himself to their satisfaction. He died before them, and the court held, relying on Halfhead v. Shepherd, that he did not take because the power could never have been exercised. Porter, M. R., said: "I am not aware of any case, and believe none can be found, in which the implied estate in default of appointment has been held to be greater than that which could have been conferred by an exereise of the power, nor in which the implication has arisen in events which would have excluded the power."

But in Mason v. Limbery (I734), stated by Sugden from MS. (c. II, 8 18, $6 \mathrm{pl}$ ), there was a bequest to $A$ for life, whom the testator "desired at his death to give it amongst his children, and the children of his said daughter, as he should think fit;" and it was held by Lord Talbot to be a devise to the children in default of appointment; and the children were accordingly to be entitled to the fund, although $A$ died in the lifetime of the testator.

If the estator does not name any one to exercise the power, but it is clear he intended the objects to take, they will take by implication. Sugden, Powers, c. Ir, 3 , pl. 6, Hyer v. Wordale, cited 2 Freem. 135; Locton $\nabla$. Locton (1637), 2 Freem. 136; Pitt 7. Pelham (I670), I Cha. Cas. 176, a Freem, 134, and I Lev. 304, which last is against the trust, but is reversed in House of Lords. See Carvill $\nabla$. Carvill (1684), 2 Ch. Rep. 3or.

23 Express Gift Over on Default of Appointment.

Roddy v. Fitzgerald (r857), 6 H. L. C. 823, 856; Richardson v. Harrison (I885), I6 Q. B. D. 85, 102, 103, 104, 55 L. J. Q. B. 58, 54 L. T. 456-A. C.; Iyons \& Carroll's Contract (1896), I I. R. 383 .

"But where there is a limitation over upon the failure to exercise the power there is no occasion for or propriety in resorting to inferences as to the intentions of the testator, for he has declared his intentions in such event in explicit terms, and to imply a trust in such a case would defeat his declared intention. There being a valid limitation over in this case it is clear there was no implied trust coupled with the power." Atkin- son $\nabla$. Dowling (I890), 33 S. Car. 414, I2 S. E. 93.

* Gift Over Void.

In te Sprague (1880), 43 L. T. R. 236. 
An Express Gift over on One Contingency does not rebut the implication of a gift to the objects of the power if that contingency does not happen, it may even strengthen that presumption. ${ }^{25}$

$A$ Gift of Residue is not such a gift over in default of appointment as will rebut implication of a gift to the objects of the power, even though such residue is given to the donee of the power. ${ }^{20}$

$\approx$ Gift Orer if No Children, Etc.

Witts v. Boddington (1790), 3 Bro. Ch. 95, 5 Ves. 503, was a power to wife to appoint by will to children of daughters, and if there were no such children then living, he directed her to leave it to his relations. The wife's will stated that out of respect to her husband she left the property unappointed. The gift over in default of children itself proved the gift to them.

Doe d. Cole $\nabla$. Goldsmith (I816), 7 Taunton (2nd E. C. L.) 209, 2 Marsh. 517, was devise to $F$ for life, remainder in such shares as he should appoint to his heirs of his body, and for want of such to $J$; $F$ was held to take an estate tail by implication.

Kennedy v. Kingston (I821), 2 Jac. \& W. 43r, 5 Gray Cas. (2nd Ed.) 337, holds that the children take in default of appointment under the power given to the mother to appoint them, though there was an express gift to them if the mother die before testator, which did not happen. This gift over also merely strengthens the implication of a gift to the children in default of appointment.

Fenwick v. Greenwell (1847), to Beav. 412, II Jur. 620, was a power to A to appoint to the children of the marriage, if any, and if none, that $A$ might appoint to anyone; and this gift over in default of appointment was very properly held not to rebut the gift to the children implied from the power. In fact a gift to $A$ for life with power to appoint rhom she pleased if she had no children would seem sufficient to raise an implied gift without any power to appoint them.

Butler v. Gray (1869), L. R. 5 Ch. App. 26, 39 L. J. Ch. 291, 18 W. R. 193, was a power to children having income for life by the prior terms of the will to appoint the principal to their children with gift over if no children, and it was held there was an implied gift to the children's children.

Jeffery's Trusts (1872), L. R. I4 Elg. Cas. 136, 42 I. J. Ch. 17, 26 I. T. 821, was a bequest of income to separate use of daughter for life, then as she should appoint among her children "and in default of such direction or appointment" then to such persons as she should appoint. She married and made an appointment to her husband, reciting that she had no children; later she died leaving children, and Malins, V. C., held that the power to appoint others existed only if she had no children, that the appointment was roid, and that her children took by implication.

Smith v. Floyd (1893), 140 N. Y. 337, 35 N. E. 606, in which Maynard, J., giving the opinion of the court, says: "There is no gift over of the remainder in case the life tenant failed to exercise the power, and there is 2 gift over in case he died without leaving children surviving him. This raises a very strong presumption that he intended the children, if there were any, should have the property on the death of their father, which in the absence of words expressly rebutting it, would ordinarily be deemed conclusive upon the question of the character of the power granted."

MeAlpin's Estate (Ig05), $211 \mathrm{~Pa}$. 26, 60 Atl. 321, though her power was to appoint - whom she pleased.

$*$ Gifts of Residue.

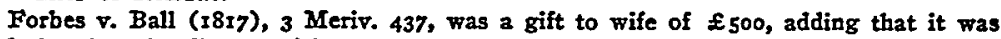
his desire that she dispose of it among her relations by will as she might think proper; and there was a residuary clause giving to her for life with gift over. The power was held rell exercised; but Grant, M. R., held a trust was raised to her relations subject to her power.

Healy v. Donnery (1853), 3 Is. C. Ir. 213, was a devise of land to daughter in trust to her use for life of the rents, with power to her to dispose of the land by deed or will to her children, fith gift of residue to her. She did not exercise the power; and efectment by her heir was sustained on the ground that she took absolutely. 


\section{Who Take Under Gifis to Defined CLasses- CHILDREN, ISSUE, ETTC.}

Under Gifts Implied from Mere Powers-General Rule. All those and those only take who might have been appointed.2t

If But One he takes the whole. ${ }^{28}$

If the Power is Exercisable at once by Deed or Will the estate vests by the implied gift at once, liable to be divested by the exercise of the power, but not by the death of a member before appointment. ${ }^{29}$

In re Brierley (1894), 43 W. R. 36,-A. C., was a fund given to trustees to the use of wife for life, with power to her to appoint, the fund "to such of my relatives or nex: of kin as she may think proper;" and the wife was made residuary legatee. The question was whether there was a gift by implication to his next of kin; and the court held, after reviewing the prior decisions, that a gift of the residue was not such a gift over as rebuts the implication of a gift to the next of kin from the porrer to appoint them; wherefore the wife was not entitled to the fund under the residuary clause if the power was not exercised.

Dunn v. Morse (1912), I09 Me. 254, 83 Atl. 795, was a power to the trustee to nominate needy relatives to such amount as they deem advisable, the residue to be given to charity, and under these circumstances the court thought relatives had no claim in absence of nomination under the power, which seems to have been testator's intention.

IT General Rule-All Take Who Might be Appointed.

Walsh v. Wallinger (1830), 2 Russ. \& M. 77, Tamlyn 425, 9 I. J. Ch. 7, so says Sir John Leach in this case, although he holds that the power might be exercised by deed and was in part, and yet he excludes those who died before the donee of the power.

The Statute to Prevent Lapse by death before testator, (I Vict., c. 27, 33), has been held not to enable persons to take by appointment who die before the donee of the power which was exercised by will, nor to enable such persons to take by the gift implied in default of appointment. Freeland v. Pearson (1867), I. R. 3, Eq. Cas. 658, 36 L. J. Ch. 374, 15 W. R. 419.

23 If One He Takes.

Bellasis v. Uthwatt (I737), I Atk. 426; Davy v. Hooper (1710), z Vern. 665; Madoc v. Jackson (1789), 2 Bro. Ch. 588; Herrick v. Fowler (1902), 108 Tenn. 410, 67 S. W. $86 \mathrm{I}$, a void attempt to appoint to such person for life, remainder to her children.

Powers Exercisable at Once.

Casterton v. Sutherland (1804), 9 Ves. 445, 5 Gray Cas. (2nd Ed.) 336, was a devise of freeholds to wife for life, then among "all our children as she should appoint in her lifetime or by will;" and the court held the remainder vested in the children at once, and the shares of those dying before the widow descended to their heirs. She never exercised the power.

Grieveson $\vee$. Kirsopp ( 1838 ), 2 Keen. 653 , was a power to a widow with assistance of the trustees to sell land and divide proceeds among the children. She survived all the children, did not sell, and attempted to appoint the grandchildren. The court held the appointment void, and that the land-vested in the children as personalty subject' to her exercise of the power to alter the proportions, but not defeated by death before her.

Falkner v. Wynford (1845), 15 I. J. N. S. 8, 5 Gray Cas. (2nd Ed.) 339, was a bequest of government securities to trustees to pay the income to the daughter for life, then to pay the principal among the children as she should by deed or will direct. She had three children, of whom one died before the testator, another before the daughter, and the other later. The power was never exercised. Wigram, V. C, held the expectancy vested in the children at the death of the testator, because "there was nothing to oblige the tenant for life to suspend her judgment as to the parties who shall take till her death."

Wing v. Fenwick (1849), II Bear. 438, 18 I. J. Ch. 337, I3 Jur. 996, was a settiement of a fund if A should die before her husband, a child then living, in trust for all 
If, without preceding estate, power is given to executors or trustees to appoint, all living at the creation of the power take under the implied gift. ${ }^{30}$ If preceded by a life estate, all born before the time for distribution are included.si Power to a life tenant to appoint by deed or will to children or the like vests the implied gift at once, and the representatives of members dying before the life tenant share. ${ }^{22}$

and every such children as she should-by deed or will appoint, and if no issue living, then as she should appoint to anyone. She had children, some of whom died before her, was survived by her husband, and did not appoint. The Master of the Rolls said none could take that could not be appointed and all could take who could be appointed; but as the power was to arise only if a child survived her, children who died before her could not take. Of this case Sugden says: "It may be considered doubtful whether this construction gave effect to all the words of the settlement which the court intended to construe by implication; for the power clearly embraced all and every the children, and might have been executed in favor of all, although it would not have taken effect unless some one survived their mother." Powers, c. 21, 8 6, pl. 27.

Stolworthy v. Sancroft (1864), 33 I. J. Ch. 708, 10. Jur. (N. S.) 762, 10 I. T. 223, 22 W. R. 635, was to trustees to pay income to A for life, and if she left issue to dispose of the property among such issue, as $A$ should by deed or will appoint. She made 2 void exclusive appointment, and the court held the implied gift was only to issue living at her death.

Wilson v. Duguid (1883), 24 Ch. D. 244, 53 I. J. Ch. 52, 49 L. T. 124, 32 W. R. 945, was a marriage settlement of leaseholds to trustees for the use of the daughter and her husband for life, and after the decease of the survivor without children, in trust for the son for life, and after his decease, to assign among such of his children as he should appoint. The son had ten children, of whom three died before the son, two died later before the daughter, and one died later before the daughter's husband. Chitty, J., held the expectancy vested in all the children subject to the son's power of selection, which was never exercised.

Re Walford, Kenyon v. Kenyon (1911), 55 Sol. J. 384, was a bequest to A for life, "semainder, as he shall by deed or will, and in his sole discretion appoint among the said" son and daughter; and on summons to determine who took' on A's death without executing the power, the.son having died before him, Joyce, J., held that the daughter and the representatives of the son took equally. "The discretion not being exercised the trust takes effect in favor of the class."

s Longmore v. Broom (1802), 7 Ves. 125; Walter v. Maunde (1810), 19 Ves. 424; Wetmore v. Henry (I913), 259 III. 80, I02 N. E. 189, to appoint heirs according to need, and some die before trustee.

21 Power to Appoint Remainder.

Stolworthy v. Sancroft (1864), 33 L. J. Ch. 708, 10 I. T. 223, I22 W. R. 635, ro Jur. (N. S.) 762, was a gift of real estate upon trust for A for life, and "in case she should leave issue, then in trust to dispose of his said estate in such manner amongst such issue" as A should by deed or will appoint. A willed it to four of her children excluding remoter issue and three of her children and the issue of two deceased children. The court held the power non-exclusive on leaving issue to appoint such issue, though the appointment might be made by deed; wherefore the appointment was void and all issue surviving her took equaliy per capita.

Carthew v. Euraght (1872), 20 W. R. 743.

Bull v. Bull ( 1830$), 8$ Conn. 47 , is manifestly the result of the failure of the court to note the difference between that case and Longmore v. Broom (2802), 7 Ves. I24, where there was no postponement of distribution.

2 By Deed or Will.

Madoc v. Jackson (1789), 2 Bro. Ch. 588; Casterton จ. Sutherland (1804), 9 Ves. 445 ; Jacleson's Will (1879), 13 Ch. D. 189. 
If the Power was Exercisable by Will Only the gift implied from the power is to those only who survive the donee of the power. ${ }^{38}$

Winn v. Fenwick (1849), II Beav. 438, was a settlement in trust for A for life, and if his wife died before him leaving any child living at her death, then in trust for all the children of $\mathrm{A}$ by such wife, as she should appoint by deed or will; and it was held that only the children surviving her could take by the implied gift. So also Stolworthy v. Sancroft (1864), 33 L. J. Ch. 708, 10 I. T. 223, 12 W. R. 635, 10 Jur. (N. S.) 762 .

23 By Will Only.

Kennedy $\nabla$. Kingston (182r), 2 Jac. \& W. 43T, 5 Gray Cas. (2nd Ed.) 337, was a bequest of $£ 500$ to Ann for life "and at her decease to divide it in portions as she shail choose to her children." She appointed by will half to a child who died before her and the rest to her other children. The court held the power was exercisible at her death only, and that those who survived her were entitled to the shares appointed to them; and as to the unappointed part were entitled to all of that under the implied gift, as they only could be appointed.

Reid v. Reid (1858), 25 Beav. 468, to widow for life, "to be disposed of at hei death among my children as she shall think proper," held that appointment to children for life, remainder to their children, was void as to the remainder, which went as in default of appointment only to children surviving her, because the power was held e'.ercisible by will only.

Brown v. Pocock (1833), 6 Simon 257, was a bequest of a fund to be set aside to make $£_{2}$ a week for A for life, with power to him to leave it to his wife and children. Then he had four children, two born later, and one and wife died before him. It was held the survivors took the whole fund, not as sole donees, but as surviving joint tenants.

Moore v. Ffolliot (1887), 19 L. R. Ir. 499, 5 Gray Cas. (2nd Ed.) 352, was a gift of "the entire of my property" to three nieces during life, "in leaving my property to my three nieces as co-heirs, it is my wish that if my nephew James conducts himse'f to their satisfaction, they shall leave to him the property I now leave to them." James died before the nieces; and it was held that the power was exercisible by will only, and the gift to him, being only in case he survived them, had failed.

Herrick $\checkmark$. Fowler (1902), 108 Tenn. 410,67 S. W. 86x, dictum, appointment tó survivors excluding issue of deceased, sustained.

What Confines Power to Will Only.

Freeland v. Pearson (1867), L. R. 3 Eq. 658, 36 I. J. Ch. 374, I5 W. R. 419, was a will in these words: "I also direct her, my dear wife aforesaid, to pay my funeral expenses and all my just debts, and at her decease to make such a distribution - * among my children as may seem just and equitable according to her best discre. tion." The widow appointed by deeds to two of the children part and the rest to all equally by will, except that one was to take $£_{5}$ only. One of the sons appointed died before his mother. Romilly, M. R., held the power was to appoint by will only, and that the shares appointed to the son who died passed to the surviving children equally by gift implied in default of appointment. He said: "This question is really simply a confict of authorities. In the case of Kennedy $v$. Kingston, I really think this very same question arose; it is as close to this case as it can well be. The same question also arose in Reid v. Reid, 25 Beav. 469, in which I seem to have followed the rule that is laid down in Kennedy v. Kingston, 2 Jac. \& W. 43I; and these two cases are, in my opinion, not distinguishable from the present. But then $I$ am referred to fwo other cases,-viz., In re Mortlock's Trusts, 3. K. \& J. 456, and In re David's Trusts, John. 495, in which the opposite seems to have been decided. However, on looking at those cases as carefully as I can, the point does not seem to me to have been raised by counsel in either of them; it does not seem to have been argued, and the two earlier cases to which I have referred do not seem to have been cited. I think, if it depended on this alone, I must follow the cases in which this point has been expressly determined after argument, and not the cases in which, possibly because, as it sometimes unfortunately happens, both sides may have wished the court to decide in 2 particular way, the authorities were not fully brought before the court. Two other cases were cited by Mr. Marten, on which 
If. the Only.Words of Gift are the Direction to Divide those only take by express gift who survive the time for division, though no divisior be actually made; and the survivors take it all. A number of cases of gifts implied from powers seem reconcilable only on this principle. ${ }^{84}$

Power to Appoint "Family," "Relations," Ettc. Who takes in default of appointment to "family," whether, heirs, next of kin, or children, depends on the context, the state of the family, etc., and the rule seems not entirely clear. ${ }^{85}$ Powers to appoint "heirs" have not

he placed considerable reliance. One was Tomlinson v. Dighton, I P. Wms. 149; but I think that the question did not arise there. Mr. Marten cited it for the purpose of showing that this was a power which could be exercised by deed; but the words in that case are very different from the rords here, which are: "at her decease, to make a distribution and disposal of them;" whereas in Tomlinson $\nabla$. Dighton it is to the wife for life, and "then to be at her disposal, provided it be to any of her children, if living, if not, to any of his kindred that his wife shall please." Therefore, though the objects of the power are specified, if there are any children, to be those children, it is expressly directed that it shail be at her disposal at any time, and not merely to be at her disposal at her decease. The otber case was the case of Ex parte Williams, I Jac. \& W. 89. There the testator gave all his real and personal estate to his wife for her life, "to be by her divided, according to the best of her judgmerit and diseretion, among such of his children and their issue as should be surviving at the time of her decease." There is nothing at all there specifying that it is to be done simply at her death, and therefore I think that both those cases are distinguishable from the cases of Kennedy $v$. Kingston, and Reid v. Reid, in which the point was expressiy determined."

"Words Haking Implied Gift Contingent on Surviving Time for Division.

Madoc $\nabla$. Jackson (1789), 2 Bro. Ch. 588, was a settlement of leasehold to husband and wife for life, and if they leave issue to the issue as the survivor should appoint; and it was held that the only child of the marriage took in default of appointment, though it died before the survivor.

Halfhead $\vee$. Sheppard (1859), I E. \& E. 918, was a devise of land to testator's wife for life with order to $R$ if surviving to divide among testator's children immediately on wife's death, in such manner as he should think equitable and fair as they severally reached $2 x ; R$ survived, and it was held that though two children reached $2 x$, the whole gift failed by the death of all before the wife.

Carthew $\nabla$. Euraght (1872), 20 W. R. 743, was a direction to trustees to divide the fund after the death of testator's widow among such of the children or remoter isste of $I$ as the trustees should see fit; and the six children of $\#$ who survived the widow were held entitled to the whole fund.

" Power to Appoint Members of "Pamily."

Wright v. Atikyns (1810), 17 Ves. 255. (1813), Ves. \& B. 313, (1814), 19 Ves. 299, (1815), G. Coop. III. (1833), I Tur. \& R. I43, a devise to mother and her heirs in full confidence that at death she would provide for testator's family, holding mother could cut timber in husbandlike manner, and that family means heir, unless controlled
by the context.

Cruwys $\nabla$. Colman (1804), a Ves. 319, a gift to sister for life, "and it is my absolute - desire that" such sister and executrix "bequeath to those of her own family" provided they behave well to her, and this was held a trust for her next of kin, in default of appointment.

In re Hutchinson ( 1878 ), 8 Ch. D. 540, 39 I. T. 86, 26 W. R. 904, holding gift to wife "absolutely with full power" to dispose for the benefit of my family gave to her beneficially and absolutely, not as trustee, and saying family means children exclud-
ing wife.

Sinnott v. Walsh (1879), 5 I. R. Ir. 27, holding an appointment to grandehild void under gift "to fall to whateres member of my family he may be disposed to will it to," 
been much discussed as to the gift resulting by implication. ${ }^{36}$ Only next of kin can be appointed under a non-exclusive power to appoint "relations." Br But one not next of kin may be appointed if the power is exclusive. ${ }^{88}$ In both cases the gift in default of appointment is to next of kin only..$^{30}$

and that all children living at death of donee of power take under gift implied in default of appointment.

Lambe v. Eames (5871), I. R. 6 Ch. App. 597, 40 I. J. Ch. 447, 25 I. T. 175, 19 W. R. 904, was a bequest to testator's widow of everything "to be at her disposal in any way she may think best for the benefit of herself and family;" and it was held that if this were not an absolute gift to the widow she violated no trust in giving a portion to an illegitimate child of a son of herself and the testator, leaving portions also to their own children.

Derse v. Derse ( 1899 ), 103 Wis. 113,79 N. W. 44, holding "sole control" * " "to devise and bequeath to the several members of my family" given to wife by testator having ten children, means children.

28 "Heirs."

Doe d. Cole v. Goldsmith (1816), 7 Taunton, (2 E. C. I ) 209, 2 Marsh. 517, was a devise to $F$ for life, remainder to the heirs of his body in such shares as he shr uld appoint, and in default of such heirs to $J$, and it was held that $F$ took an estate tail by implication.

Wetmore $\nabla$. Henry (1913), 259 III. 80, 102 N. F. 189 , was a power to one heir by will to appoint residue among testatrix's heirs, under which he paid $\$ 500$ to one taking receipt in full, and died, after which the residue was apportioned among all heirs equally.

Wilson v. Van Epps (1902), 38 N. Y. Misc. 486, appointment to children held valid though life tenant with power to appoint to his "heirs" had mortgaged in fee.

Dominick . Sayre (1850), 3 Sandf. (N. Y.) 555, "with power to give the same to descendants."

n" "Relations."

Pope $\nabla$. Whitcombe (1810), 3 Meriv. 689, residue to wife for life, and if son die without issue (so died before testator), she to dispose among his relations; held appointment to illegitimate nephew void, and next of kin at testator's death take, including representatives of two who died before wife.

Chapin's Will (1865), z Dr. \& Sm. 527, 34 I. J. Ch. 578, I2 I. T. 526, 13 W. R, 646, holds that an appointment to one not a relation is void under a power to appoint to life tenant's "relations or friends;" and that next of kin take by implied gift.

In se Deakin (1894), 3 Ch. D. 565, holding an appointment by an illegitimate person good as to her brothers and sisters except to an illegitimate child of a sister, under a gift to her "relations as she may direct."

Lawlor v. Henderson (1876), Ir. R. Io Eq. I50, holding gift of residue amongst his relations as his executors should think fit, entitled sole child to all on suit by executors for instructions.

Varrell v. Wendell (1846), 20 N. H. 43I, holding an appointment to next of kin and others wholly void, under a direction to apportion to my relations according to her discretion.

Levi v. Fidelity Trust, \&c, Co. (1905), 121 Ky. 82, 89, 88 S. W. 1083, is contra without discussion, point not raised.

so Harding v. Glyn (1739), I Atk. 469, 2 White \& Tudor 1077, 5 Gray Cas. (2nd Ed.) 324

Grant v. Lynam. (1828), 4 Russ. 292, 6 L. J. Ch. (O. S.) I29, leasehold to wife for life with power to dispose at her decease "to anyone of my own family" held well appointed to relative not next of kin.

Mahon v. Savage (1803), I Scho. \& Lef. (Ir.) IIr, permitting executor to include relations not next of kin, though the power was to divide among poor relations.

Levi v. Fidelity Trust \&c. Co. (Ig05), I21 Ky. 82, 88 S. W. I083, sustaining appointment not to next of kin, though the power was "distribute to her relations." 
Same-When Determined. The next of kin taking under the gift are determined at the death of the life tenant, whether the power be exclusive or not, and whether exercisable at any time or by will only..$^{0}$ The donee of the power is generally the tenant for life; but the same rule has been applied though the donee of the power was another person.:1

The notion that the donees under such implied gifts should be as-

Drew v. Wakefield (1865); 54 Me. 29I, 299, "to deserving relations and such indigent persons as they may think worthy," enables trustees to name those not of kin.

Varrell v. Wendell $(1846), 20$ N. H. 43I, dictum.

Huling .v. Fenner ( 1870$), 9$ R. I. 410 , though also objected that appointee was not of the name of donor.

Meldon v. Devlin (1898), 31 App. Div. 146, 53 N. Y. Supp. 172, sustains payment by trustees to one born after death of testator, the trust being to apply so much of the income as they see fit to A, B, C, "or their respective widows and issure."

Jones's Estate (1893), 84 Wis. 465, 54 N. W. 917, "nearest relations" entitled to appointment of administrator de bonis non.

" "Relations" Implies Gift Only to Next of Kin.

Doyley v. Atty. Gen. (1735), 4 V̧in. Abr. 485, pl. 16, 5 Gray Cas. (2nd Ed.) 333.

Spring v. Bayles ( 1783 ), I Term. 435, 438n, was a power to the widow to dispose' "among such" of my relations as shall be living at my decease," and held not confined to selations before mentioned and an exclusive appointment good.

Cole $v$. Wade (1806), 16 Ves. 27, 2 devise of residue, real and personal, to executor on trusts named, and finally to dispose to such relations as they thought proper, preferring the nearest and most deserving, which the court confined to next of kin on death of the trustees.

Salusbury v. Denton ( 2857 ), 3 Kay \& J. 529, "to be at her disposal among my relatives" not exercised entitled next of kin.

Mahon v. Savage (1803), I Sch. \& L,ef. III, dictum, was a bequest of $f$ I,000 to the executrix to be distributed among testator's poor relations, and held exclusive because charitable.

Varrell v. Wendell (1846), 20 N. H. 43r, "to be apportioned to my relations secording to her discretion, to be enjoyed by them after her decease," was divided among next of kin though she had attempted to appoint them and others.

Ievi v. Fidelity Trust \&c. Co. (1905), I21 Ky. 82, 88 S. W. 1083, dictum, "because a range so illimitable would render the trust uncertain."

Huling จ. Fenner (1870), 9 R. I. 410, dictum.

4 Remainder to "Relations."

Pope v. Whitcombe (1810), 3 Meriv. 689, more aceurately reported in Sugden onPowers, c. 15, \& 2, pl. 13; Harding v. Glyn (1739), I Atk, 469, 2 White \& Tudor, ro77; Cruwys v. Colman (1804), 9 Ves. 319, 325; Birch v. Wade, 3 Ves. \& B. I98 (1814); Finch v. Hollingsworth (I855), 21 Beav. 112.

Finch v. Hollingsworth (1855), 21 Beav. II2, was gift by will of residue, real'and personal, to the wife for life, then to be distributed one-half to her relations, and the other half to testator's relations as his wife should by will appoint. 'Testator's two brothers and sole next of kin at his death died before the widow, and she appointed to their children. It was objected that the appointment was excessive; but Romilly, M. R., held the appointment good because the relations were to be ascertained at the death of the donee of the power, not at the death of the testator.

Allen v. Almy (1913), 87 Comn. 517, 523, 89 Atl. 205, was a trust to pay income to daughter for life, then to her issue, but if she leave none (happened) "then to my heirs" excluding her; and it was held the heirs should be determined at testator's death. Note that this is an express gift.

a Doyley v. Atty. Gen. (1735), 4 Vin. Abr. 485, pl. 16, 5 Gray Cas. (2nd Ed.) 333, the trustees. 
certained at the death of the life tenant seems very strange in view of the established rule that "heirs," "next of kin," "relatives," \&c., are in express gifts always those answering that description at testator's death. ${ }^{41^{\star}}$

"Poor," etc., defining the class of heirs, relations, etc., to be appointed, have been differently construed in different cases; but it is believed the restrictions should not be disregarded by the court, and 'should be determined at the time for division. ${ }^{42}$

4s See Rood on Wills, 840 .

42 "Poor Relations." 683 .

So declared by Prof. Gray: 25 Harv. Iraw Rev. 28. Rule against Perpetuities,.

Widmore v. Woodrofie (1766), Amb. 636, was a decision that a direction to distribute "among the most necessitous" of his relations was to be read next of kin only;" because the court cannot distinguish degrees of poverty.

Carr v. Bedford (1678-9), 2 Ch. Rep. 146 , was a bequest of residue to be divided among testator's kindred according to their most need, and decreed that in making distribution the executor should proportion the property among the next of kin, as he should think them most in need; followed in Griffith $\vee$. Jones (1786-7), 2 Ch. Rep. -94.

Green v. Howard (I779), I Bro. Ch. 3r, contains a dictum by Thurlow, Ch., that the court will regard the need of relations as directed by testator, when it comes to determining proportions, though none but next of kin can participate.

Carthew 7 . Euraght ( 1872$), 20$ W. R. 743, was a direction to trustees to give to those children and descendants they should deem most to require it, and the court divided it equally to all.

Mahon v. Savage ( 1803 ), I Scho. \& I.ef. (Ir.) III, a gift to executor of $\{I, 000$ to distribute among poor relations was.held not to extend to one poor when testator died but rich when the executor was to distribute, nor the representatives of one living at testator's death but dying before distribution.

Lawlor v. Henderson ( 1876$)$, I. R. 10 Eq. I50, was a direction to executors that at the death of the annuitants therein named they should distribute the rest of his estate among his relations as his executors should think fit and most worthy to receive it. The court held that testator's daughter was entitled to the whole' fund, she being his sole next of kin at his death and at the death of the annuitants. The reason for the decision was that the power was to distribute, not to select, relying on Pope $r$. Whitcombe (1810), 3 Meriv. 689.

Bull v. Bull ( 1830$), 8$ Conn. 47 , holding the needy are to be determined at testator's death, not at the time for division.

Wetmore v. Henry (1913), 259 Ill. 80, I02 N. E. I89, was an even division by the court of the part not appointed by the trustee deceased, which was to be given to the heirs "as he in his discretion shall deem each of them worthy."

Drew v. Wakefield (1865), 54 Me. 291, dictum, that if trustee were not acting next of kin would take under direction to distribute "to deserving relations and such indigent persons as they may think worthy."

Gafney v. Kenison (1887), 64 N. H. 354, 10 Atl. 706, holding a direction to divide the interest for ten years among "the most destitute of my relatives, not to extend beyond the children of my brothers and sisters and their families," was not void for uncertainty.

MeNeilledge v. Galbraith (I8a2), 8 S. \& R. (Pa.) 43, a direct gift, to "poor relations," holding that the gift is to be read as if the word "poor" were omitted, because the court is unable to determine degrees of poverty: Followed in McNeilledge v. Barclay (1824), II S. \& R. (Pa.) 103.

Fontaine v. Thompson $(\mathbf{1 8 8 5}), 80 \mathrm{Va}$, 229, was a gift of residue in trust for the most needy next of kin, and the court refused to consider the needs of the next of kin, expressiy disapproving of Bull 7 . Bull above. 


\section{Method of Division of IMpLIfd Grits-Per Capisa OR PER STIRPES.}

Heirs, Issue, etc., take per capita under gifts implied from powers. ${ }^{13}$

Charities take an aliquot part and the relations an eliquot part between them."4

"Or" and "And." A power to appoint to persons or their descendants has been held substitutionary, not entitling descendants of living persons to participate in the gift implied in default of appointment, though the donee of the power might have appointed either. ${ }^{45}$ The same has been held of a power to appoint to a class and their descendants. ${ }^{40}$

At the contrary extreme, or has been read and, permitting chil-

4 "Heirs" Take Per Cupita.

Iongmore v. Broom (1802), 7 Ves. 125; Brown v. Pocock (1833), 6 Sim. 257 ; Grieteson v. Kirsopp (1838), a Keen 653; Burrough v. Philcox (1840), 5 Myl. \& C 72; Stolworthy v. Sancroft (1863), 33 I. J. Ch. 708, I0 L. T. 223, 22 W. R. 635, 10 Jur. (N. S.) 762 .

White's Trusts (I860), I Johns. 656, was a direction to trustees to divide among "such other of my children, or their issie, as they may think fit," in case the son die childless; and it was ordered that children and remoter issue take per capita.

McGaughey v. Henry (1854), 54 Ky. (15 B. Mon.) 383, 398, no discussion.

Wetmore v. Fenry (19.3), 259 IIl. 80, 86, 102 N. E. 189, to be divided among heirs not completely executed goes as to unappointed part equally to all per capita, not per stirpes.'

MeNeilledge v. Galbraith (2822), 8 S. \& R. ( $\mathrm{Pa}$.) 43, "to be divided between her and my poor relations equally," take per capita rich or poor according to the statute of distributions.

4 Cheritices.

Doyley v. Atty. Gen. (1735), 4 Vin. 485, pl. I6; Salusbury v. Denton (1857), 3 Kay \& J. 529, 26 I. J. Ch. 85I, Jur. In. s. 740, 5 W. R. 865; but see, Hunter v. Atty. Gen. (I899), L. R. App. Cas. 309, 68 I. J. Ch. 449, 80 I. T. 732, 47 W. R. 673,-且. I.

Dunn จ. Morse (1912), I09 Me. 254, 83 Atl. 795, holds that the charity is entitled to the whole fund on default of appointment under-a power to trustees to appoint such part as they see fit to needy relations and the rest to charity, because default indicates intent to appoint none to relations.

4 "Or" Implying Substitutionary Gift.

Jones v. Turin (1833), $6 \mathrm{Sim}$. 255, was a bequest to trustees, for daughter for life, then to the children of named persons or their descendants as she should appoint; and in delault of appointment it was held that the descendants were mentioned only as aubstitutes for children.

Children or Grandchildren. Rogers v. Rogers (1859), 39 Tenn. (2 Head) 660, held that children of living children, could not thare in the gift implied in default of appointment to children or grandchildren.

"And" Implying Substitution.

Tucker $\nabla$. Billing ( 1856 ), 2 Jur. n. 8. 483, was 2 power to appoint brothers and sisters and their descendants, and it was held that descendants could take in default of appointent only in case their ancestors did not.

Eaton v. Eaton (I9I4), 88 Conn. 269, 91 Atl. I9x, was a direction to trustees to pay incoine to children for life, then corpus to their children, "and I hereby devise and bequeath the same to such children and their descendants," was clearly substitutional. 
dren of a living sister to take under a gift to sisters or their children. ${ }^{47}$

A power to appoint to persons and their issue has been held to imply a gift in tail to the persons in default of appointment, issue taking nothing: ${ }^{48}$

\section{University of Michigan Law School.}

JoHN R. ROOD.

17 "Or" "Read "And" Not Substitutional.

Penuy $v$. Turner $(2848)$, 2 Phil. 493,15 Sim. 368 , was a devise to mother for life, then to be divided among his three sisters or their children as she should appoint; and she and one of the sisters died before him, (the sister without children), and one of the surviving children had two children. It was held that or meant and so that there were five shares under the gift in default of appointment, of which one share lapsed by death to testator's two surviving sisters as his heirs.

Langmore v. Broom (1802), 7 Ves. 124, in trust to divide among brothers and sisters or their children, was given to all per capita in default of the trustees.

Same. "My Children or Their Issue," was held not substitutional, under a power to appoint to the other children or their issue if the son die childiess, and division was made per capita among the children and all issue living at the time of division. In re White's Trusts (1860), Johns. 656.

Carthew $\nabla$. Euraght (1872), 20 W. R. 743, was a direction to trustees to divide among such of the "ten children, grandehildren, and other descendants" of an uncle as trustees deemed most to require it, and all persons living at the time for division were decreed to share equally - viz. two children, a grandchild and three great-grandchildren.

13 "And Issue" Implies Estate Tail.

Martin v. Swannell (1840), 2 Beav. 249, 9 I. J. Ch. 174, was a devise to vife for life and on her death to his three children and their issue as she should appoint; and on her failure to appoint, Iangdale, $M$. R., held they took estates tail.

To Son and Issue to be Divided by Him. Hockley v. Mawbey (I790), I Ves. Jr. 143, was a devise of freeholds and leaseholds to testator's son and his issue, to be divided among them as he should think fit, and in case he should die without issue, over; and it was held that the son had a life estate in the leaseholds, and that he had merely power to alter the shares of the children, not to decide whether they should take, if there had been any. 